\title{
THE PORTRAYAL OF NATIONAL IDENTITY IN THE FILMS OF MALGORZATA SZUMOWSKA
}

\begin{abstract}
Matgorzata Szumowska is without a doubt one of a few Polish directors who has managed to distinguish herself on the European film market. Although, Szumowska is a cosmopolitan (in Ulf Hannerz's terms), she does not forget about her Polish origins. On the contrary, she emphasizes contemporary Polish identity of her protagonists and Polishness in itself but does it from the external perspective. In her feature films, Małgorzata Szumowska defines Polish identity, according to Antonina Kłoskowska's theory, as a phenomenon which always exists in a specific social and cultural context. From this perspective, Polishness is constantly negotiated and renegotiated by film protagonists. The author will distinguish three categories through which the director defines Polishness, these are: cultural trauma, national character and modern Catholic religiousness. These categories will be analyzed on the basis of specific examples. An applied methodological approach relies on cultural poetics assumptions, also known as new historicism.
\end{abstract}

Key words: Polish national identity; the cinema of Małgorzata Szumowska; cultural trauma; national character; Catholicism

\section{PORTRET TOŻSAMOŚCI NARODOWEJ W FILMACH MALGORZATY SZUMOWSKIEJ}

Streszczenie

Niewątpliwie Małgorzacie Szumowskiej jako jednej z niewielu polskich reżyserek udało się przebić na europejskim rynku filmowym. Chociaż Szumowska może być uznana za kosmopo-
GRZEGORZ WÓJCIK Uniwersytet Jagielloński, Kraków E-mail: grzegorz.wojcik87@gmail.com

CITATION: Wójcik, G. (2017).

The Portrayal of National Identity in the Films of Matgorzata Szumowska. Sprawy Narodowościowe. Seria nowa, 2017(49). https://doi.org/10.11649/sn.1448

This work was supported by the author's own resources. No competing interests have been declared.

This is an Open Access article distributed under the terms of the Creative Commons Attribution 3.0 PL License (creativecommons.org/licenses/by/3.0/pl/), which permits redistribution, commercial and non-commercial, provided that the article is properly cited. (C) The Author(s) 2017.

Publisher: Institute of Slavic Studies, Polish Academy of Sciences 
litkę (w rozumieniu Ulfa Hannerza), to nie zapomina ona o swoich polskich korzeniach. Przeciwnie, w swoich filmach podkreśla zainteresowanie współczesną Polską i polskością, ale czyni to niejako z perspektywy "zewnętrznej". Wykorzystując teorię tożsamości narodowej autorstwa Antoniny Kłoskowskiej, autor wskazuje, że Szumowska w swoich filmach fabularnych postrzega tożsamość narodową jako fenomen obecny zawsze w określonych warunkach społeczno-kulturowych. W tym ujęciu polskość jest nieustannie negocjowana i renegocjowana przez filmowych protagonistów. Autor wyróżnia trzy kategorie, poprzez które reżyserka określa polskość: traumę kulturową, charakter narodowy oraz religię katolicką, które analizuje na konkretnych filmowych przykładach. Zastosowane podejście metodologiczne wykorzystuje postulaty poetyki kulturowej zwanej również nowym historyzmem.

Słowa kluczowe: polska tożsamość narodowa; kino Małgorzaty Szumowskiej; trauma kulturowa; charakter narodowy; katolicyzm

M atgorzata Szumowska is without a doubt one of the few Polish directors who has managed to distinguish herself in the European film market. Her films are made in cooperation with foreign partners and many of them have received awards at international film festivals - winning the Silver Bear for Best Director for her film Body/Ciało at the Berlin International Film Festival in 2015 has been her most important award to date. Szumowska's international film settings and employment of wellknown European actors, such as Juliette Binoche (Sponsoring, 2011) and Julia Jentsch (33 Scenes from Life, 2008) indicate the director's ability to interact with foreigners. Szumowska mentions, in an interview with Agnieszka Wiśniewska, that she owes this to her late parents: "I think that my parents raised me to be very self-confident. I was always inquisitive; therefore, if I had a possibility to talk with someone who lived and worked abroad, I used it"** (Wiśniewska, 2012, p. 110). Szumowska's ambiguity connected with her intellectual openness and various cultural experiences, has led her to seek contrasts and not unity, making her a model representative of the Hannerz' cosmopolitan, who has "obvious competence with regard to it, but he can choose to disengage from it. He possesses it, it does not possess him" (Hannerz, 1996, p. 104). Asked about her attitude towards Polishness, Małgorzata Szumowska stated:

I do not seem to feel a crazy connection with nationality, the flag, and the anthem ... with these shallow signs of patriotism. It seems to me that the world is now more and more unified and we are all Europeans, however stupid it sounds. And my son who is now 4 years old is sure to be a citizen of the world. Many people may take it the wrong way but I truly think so. Yet I like my Polish traits, even very much. Then maybe it is just the word patriotism that is used up (Pietrasik \& Szumowska, 2009, p. 61).

There seems to be an obvious contradiction in the above quote. On the one hand, Szumowska claims that she does not identify with her country of origin and at the same time she values her Polish traits which she defines as "a specific kind of coarseness, I would even say boorishness which is in Polish people" (Wiśniewska, 2012, p. 13). These aporias appear a few more times in her statements. When the director mentions her attitude towards Western European citizens she says that she is really pleased with the fact that she grew up in Poland, especially during the times of socialism, because as a result she gained strength which her peers in France or Germany do not possess. She also does not want

......

All translations of quotations from Polish into English are mine - Grzegorz Wójcik. 
to leave Poland and she even criticizes Western democracies, for instance Denmark for its lack of tolerance, agreeing with the statement that in Poland there is yet more freedom:

We were at a party in Denmark. When you get slightly drunk at this kind of party, break a glass or shout "fuck", not a minute passes before two security guards are at your side. They twist your arms and cuff you because your behaviour "goes beyond commonly accepted norms." When I saw this and a few other things I started to doubt. I would rather be here in our mess (Wiśniewska, 2012, p. 17).

At the same time Małgorzata Szumowska is able to appreciate the achievements of Western culture:

In Berlin everyone rents an apartment. Nobody even thinks about buying one. And here in Poland from generation to generation you need to an apartment. Today if you want it to be your own you need to buy it, in order to buy you need to take a loan, and probably your children are also to repay it. When I started to travel the world and meet a lot of new people I realized that it is not necessarily the way to live. I freed myself from Polish burdens (Wiśniewska, 2012, p. 16).

The filmmaker easily finds herself in various environments and cultures, choosing the elements which suit her personality but rooting in none. This attitude directly influences her creations, where a deep attachment to Poland and Polishness, which she still approaches critically by distancing herself from national sanctities and many times breaking the local taboo, is shown. In films she focuses on contradictions existing both in the characters she creates and between them, as well as the discrepancies existing in the Polish symbolic universum.

Antonina Kłoskowska in her book National Cultures at the Grass-Root Level (Kultury narodowe $u$ korzeni) states that while analyzing contemporary manifestations of national identity one has to bear in mind ongoing processes of national themes subjected to constant debate and subjectivism. In this way, the scholar rejects the phenomenon of "naturalization" regarding national identity:

One shouldn't pose questions regarding "Polish identity" of the Poles or ask any questions concerning the Poles in general. "Poles in general" as seen from the identity perspective are either theoretical or ideological or even political fiction. Yet, it doesn't mean that the existence of the Polish nation or the concept of nation as such is denied here. [...] but nation is understood as significant, yet one of many social collectives: a broad and complex community of communication as imagined and embodied by culture (Kłoskowska, 2005, p. 103).

In Kłoskowska's opinion, one cannot talk about the essence of national identity understood as a tool of identification, because in this way the concept is devoid of relation and contextuality. Kłoskowska assumes a certain vision of national culture understood within culture context as:

A universum common to a certain collective, which can't be learned and comprehended without taking into account the individual processes of its inner experience by its given members. Hence, national culture is a subjectively actualized phenomenon, which is inter-subjective and relates to objective facts: culture associative relations and their roots, which create the canon (Kłoskowska, 2005, p. 79).

Kłoskowska's statements can be related to Małgorzata Szumowska's cinema and her portrayal of Polishness. This is also the main subject of this article. Szumowska's protagonists are representatives of the middle class city dwellers, who while living in Giddens' 
late modernity create their own identity narrative as a reflexive project of the self. It's mainly about "maintaining a coherent, although constantly revised set of biographical narratives" (Giddens, 1991, p. 8).

The director is interested in how the protagonists re-create and re-interpret the elements of Polishness in their everyday lives. In other words, the director focuses on the subjective reactions of the protagonists to the so called "official" Polishness, that is, values, symbols, memories, myths and traditions creating Polish cultural heritage (Smith, 2007, p. 31). In Szumowska's films, and analogously in Kłoskowska's theory, national identity is constantly undergoing changes which are provoked by various situations and interactions, under the influence of a broadly understood contemporary reality.

In this essay I will focus on the portrayal of Polishness presented in Szumowska's feature films, although in my analysis I will also use her documentaries to present a broader context. In order to logically organize this essay, I will distinguish three categories through which the director defines Polishness, these are: cultural trauma, national character and modern Catholic religiousness. These categories will be analyzed on the basis of specific examples.

An applied methodological approach relies on cultural poetics assumptions, also known as New Historicism. Within this context one can connect given texts with many cultural phenomena which take place at a given time. Cultural texts, including films, should be, therefore, analyzed in a given context with regard to social phenomena presented there. Hence, films will be considered not as works of art but as cultural texts created within a given culture (Greenblatt, 2006, p. 147-148). I will not be interested in their artistic value but in the way they present socio-cultural phenomena, which are heavily related to concepts of national identity.

\section{POLISHNESS AND TRAUMA}

E. Ann Kaplan defines trauma as a breach of one's security area that results from an impossible to comprehend event from the past, which cannot be represented in language or any other form that can make it into something meaningful (Kaplan, 1998, p. 34). Hen$\mathrm{ce}$, the trauma results in shock and fear, and makes people deeply injured. Piotr Sztompka states that the notion of trauma cannot be related solely to an individual, but can also be applied to the analysis of negative, dysfunctional results of social changes, which the sociologist defines as cultural trauma. As Sztompka notices, this happens in "specific structural and cultural conditions ("favoring context") caused by previous specific social changes ("traumatic events"), interpreted as such within a given culture (Sztompka, 2000 , p. 20). This traumatic event as analyzed by Sztompka is the Polish political transformation after 1989. As a result of this transformation, society was torn apart in terms of culture, and there were two symbolic orders coexisting and not consenting. One the one hand, there was a set of cultural rules as inherited from communism and its typical habitus. On the other hand, a new cultural order started to be valid and necessary for new democratic institutions and a capitalist system. Sztompka claims: "For most of the people the clash between these two opposite cultures meant that previously inherited and internalized ways of lives become obsolete and seen as something harmful or rejected in the new system, and the new rules were for these people foreign, forced and dictated" (Sztompka, 2000, p. 56). 
In her latest film, Body/Ciało (2015), Szumowska seems to emphasize the fact that Polishness is inevitably linked with the feelings of trauma. The two-word title isn't accidental, because on the one hand the director presents protagonists forced to deal with personal trauma as caused by a close person's death, and on the other hand shows a much broader macro social perspective, agreeing with Sztompka that Poles still struggle with cultural trauma and transformation changes.

In order to emphasize the socialist roots of Poland, where the action takes places Szumowska employs a number of staging tricks. Her protagonists are characterized in a similar way. Although, the film is set in the contemporary world, through the out of fashion clothes of her protagonists the director shows that their lifestyles have not changed since socialism.

In Body/Ciało Szumowska looks at Warsaw in the way foreigners may see it, especially the ones coming from Western countries who at first notice the socialist heritage of the city. Instead of fashionable cafes and clubs dominated in media representations of the capital city middle class, the director presents blocks of flats with gloomy staircases, long hallways, and cramped elevators. This is the scenery where characters are mostly presented. Apart from observing the therapist Anna (Maja Ostaszewska) at her workplace in a hospital with patients suffering from eating disorders, viewers can see her most often in the housing estate when she gets back from work or in one of many left over after the Polish People Republic's times big grocery stores situated in the central part of the estate where she shops. This character is also shown in the elevator engaging in small talk with an elderly neighbour or in her apartment where the interior has not changed for at least 30 years. The latest feature is further confirmed by Szumowska when she talks about Anna's, the main character apartment: "it was very similar to the one I used to live in with my parents in Cracow in the 80s, there were even PCV tiles on the floor" (Sadowska, 2015, p. 94).

Prosecutor Koprowicz (Janusz Gajos) is also presented against the background of interiors remembering the times before 1989-when he eats dinner in a cheap canteen, during a visit to the head of the hospital's wainscoted office or in the staircase during a short conversation with his downstairs neighbour. By choosing this particular setting of the film, Szumowska seems to consciously refer to the Warsaw housing estate from The Decalogue (1988-1989) by Krzysztof Kieślowski where the action of all the episodes takes place. The artist appears to claim that despite the fact 27 years have passed since the collapse of communism, there are no visible changes in the city landscape and people still live and think in the same way as in the $80 \mathrm{~s}$. It is further emphasised in the scene of conversation between the prosecutor and the head of hospital where the prosecutor's anorexic daughter Olga (Justyna Suwała) is hospitalized. The conversation between the men is interrupted when the hospital head's phone rings, a desperate woman asks for her daughter to be admitted to the hospital. Despite the fact that apparently there are no free beds, the head informs the woman that after a private paid appointment with him, he may be able to find a bed.

Both the prosecutor and the therapist are the representatives of particular personality types that can be encountered in Poland. Regarding the prosecutor character, Szumowska says: "when you travel in Warsaw by bus or tram and not in your own car you start to see how common this type is. (...) like taken live from the 90 s, from a different epoch, from the world resistant to the passing time" (Sadowska, 2015, p. 94). The characters' "frozen" mentality is also indicated by their out of fashion clothes. Olga wears the so cal- 
led "Turkish" coloured patterned sweater, highly popular in Poland at the turn of 1980s and the 90s, Koprowicz wears a suede jacket and Anna an orange turtleneck, a multicolour vest, an ankle length skirt and glasses on "a string".

In Body/Ciało Szumowska presents Poland as an entirely unintegrated place lacking balance between extremities: "in the case of spiritual food (...) we either take too much or we suffer from its lack. Poland is not a country for healthy people"-says the director in one of the interviews (Sadowska, 2015, p. 92). In this latest film at the one end there is the therapist Anna who does not care about earthly matters and after work changes into a spiritualist, getting in touch with the spirits of dead people. At the other end there is the prosecutor who has both feet firmly on the ground and in his everyday life encounters only dead bodies and in terms of spiritual matters is a typical Polish spiritist-looking for hope in drinking" (Sadowska, 2015). The element that connects these characters is the difficulty of dealing with the trauma of losing loved ones. In Anna's case, it is the death of her infant son that happened a few years back and that she still cannot recover from-her son's toys and bed are still in the room. For Koprowicz-the death of his wife.

Hence, the characters are the representatives of particular personality types; it seems that by using them, Małgorzata Szumowska by using them decides to portray Polish souls. In my opinion, both Koprowicz and Anna can be seen as unique allegories of modern day Polishness. As Szumowska points out, contemporary Poles have not effectively dealt with their socialist past, and their minds are still stuck there. Yet, the political transformation of 1989 forced a change in the way people lived their lives and an adaptation to new ways of thinking and lifestyles, and Poles, who had always had a pro-West attitude, made every effort to adjust to these changes (Sztompka, 2000, p. 49). The coexistence of cultural norms distinctive from the previous and current system creates, as Sztompka claims, cultural traumas, which are greatly exemplified in Body/Ciało. In the director's view, Poles, seen as the whole nation, need collective therapy just like all her filmic protagonists do-Olga, but also the prosecutor and Anna.

Reference to the recent, traumatized Polish past, in this case connected with the tragic events during the Second World War, also appears in the director's earlier film - In the Name of... (2012). In the opening scene, a group of children play on the remnants of a Jewish cemetery in the country situated somewhere in Mazury. At one point innocent play turns into sneering and flames directed at one of the participating disabled boys. Violence which is directed at "the other" indicates that "no otherness is to be accepted here [in the Mazurian village, comment mine]" (Sadowska, 2013, p. 81). This kind of staging brings out the direct association with the slaughter of Jews in 1941 in Jedwabne by Poles. Although events from 76 years ago cannot be compared to the above described scene, the mechanism in both cases remains the same. Violence directed at "the other" does not belong to the distant past but, as Szumowska suggests, is reborn time and time again and is still present in Polish mentality.

\section{NATIONAL CHARACTER}

Renata Hołda claims that some scholars have prejudices towards the term 'national character' because in their opinion it associates anti-scientific connotations. Nevertheless, this term is very often used in academic publications because it is useful during discus- 
sions about the differences between nations and cultures. Hołda states that national character means the collection of beliefs about "our» specificity withstanded to "their" and is a part of the collective identity. The scholar affirms: "The members of a socio-cultural formation define themselves by this term, viewing the difference of national characters the interpretation of historical occurrences and meanders of current politics" (Hotda, 2012, p. 129).

It seems that Małgorzata Szumowska, in her international coproductions and work with actors from different countries, uses 'national character' in order to show the cultural differences between Poles and the people of West European nations.

Comparing Polishness with Western culture and mentality is one of the topics of Sponsoring (Elles, 2011). The plot of the film evolves around interviews carried out by Anne (Juliette Binoche), a journalist for Elle who writes an article about female students' prostitution in Paris-Polish girl Alicja (Joanna Kulig) and French Lola/Charlotte (Anaïs Demoustier). In two parallel plots, Szumowska presents the different natures of both girls directly related to their countries. A transnational perspective is visible the way the narration is handled, since the viewers see both characters (meaning also the Polish girl) from the perspective of a well-off Anne. Whereas Lola appears to be an orderly person following social rules with a slightly melancholic look, Alicja is an embodiment of spontaneity and temper. The French student arranges the interview in a park during the day, dressed in casual jeans and a T-shirt. Moreover, the setting emphasises her natural looks. On the other hand, the interview with Alicja takes place in a luxurious hotel room late in the evening, and the girl is dressed in a tight black dress and wearing heavy makeup. The course of the interviews is also very different. During the interview, Lola sits almost motionless on a bench and talks about her experiences in a calm, studied manner, trying to meet the essential expectations of the journalist. Alicja, on the other hand, colours the meeting with vodka, which she offers the journalist straight out of the bottle, then with an immoderate consumption of spaghetti, and finally, with a dance that she invites the already drunk journalist to join in with.

This manner of showing the representatives of both nations corresponds with sociologists' research exploring different nations' identities. According to Edmund Lewandowski, quoting Salvador de Madriaga's opinions, Voltaire, the intellectual and rationalist, is the personification of the French nation. The French care mostly for harmony and logic, which usually predominate over feelings and practicality. Polish identity is different. Polishness is less logical and Polish culture is not shaped by rationalism as French culture is. Polish identity embodies such values as dedication, heroism and the emotional experience of common fate (Lewandowski, 2008, pp. 93-94). The difference in presenting the girls clearly emphasises the cultural distinctions between Poland and France. Szumowska comments on them in "Newsweek" in these words:

French women are detached, tense and Polish are more liberated. Thinking that Polish women are traditional and uptight and French are liberal and open is stereotypical. In fact, it is the other way round. French women can talk about sex openly and claim that they are free and can do whatever they like, and they have their rights that we still do not have in Poland. At the same time, they are from here to there, limited and madly concerned with a hygienic lifestyle, healthy food and other crap like that (Rigamonti \& Szumowska, 2012, p. 48).

The way of presenting the Polish student seems to be closely related to the way Matgorzata Szumowska herself was perceived by her Western friends. When asked about her reception abroad, she answered: 
They think that I am crazy, that I have this Slavic openness, this model still exists, and these are the currently used clichés. The French cannot seem to stop delighting with how I eat. You are so anarchist in the way of eating, they say. Because in the morning they have coffee and a croissant, at 1 p.m. they need to have lunch, at 8 p.m. dinner and nothing between the meals. Yet they eat for a very long time and chew slowly. And I eat as I feel to, fast and then suffer a stomachache. It is so weird for them (Pietrasik \& Szumowska, 2009, p. 60).

Szumowska undoubtedly bestows some of her traits on Alicja, who in the film appears as direct, provocative and nearly lacking any boundaries.

\section{POLISH MODERN RELIGIOUSNESS}

In her works, the director many times reflects on religiousness, which is so often associated with Poles. Stawomir Mandes claims that "the tourists coming to Poland from Western Europe are invariably amazed at the sight of crowds taking part in Sunday mass, the number of churches, and the presence of religious symbols in the public space. According to many visitors Poland is to be remembered for its omnipresence of religion" (Mandes, 2012, p. 230). The model illustration of this statement is a documentary, with a slightly ethnographic undercurrent, entitled Nothing to be Scared of (2006). The film is constructed from the statements of the older residents of a Mazurian countryside regarding death and traditional beliefs concerning burial practices. While talking about funeral preparations, the protagonists seem to be accustomed to death, for example, they are not scared of sleeping in a room with the dead people. Michal Piepiórka notes that "their peacefulness and hope stem from traditions passed down for a long time which clearly present how to approach funerals and bereavement. It recalls the medieval art of dying, which gave certainty of eternal life after death and therefore peace to the dying" (Piepiórka, 2013, p. 22).

In her feature films, Szumowska focuses on the subject of religiousness among the residents of the larger Polish cities - the highly educated middle class. In contrast to the residents of the countryside, city dwellers do not refer to tradition while constructing their identities, but, in accordance to Anthony Giddens' claims, they create a narrative identity as a "reflexive project" where they take full responsibility for its creation (Giddens, 1991, p. 5). With regard to traumatic events, like the death of family member presented in 33 Scenes from Life (2008), the protagonists seem powerless and try to live through the mourning in their own solitary way. The scene of Julia's mother's funeral with all the family gathered is exceptionally evocative in this context. The long unseen middle-aged son (Roman Gancarczyk) breaks down in front of the father, although the deceased woman was not his mother. Seeing this emotional breakdown, other family members sneer at him, thinking that he is playing the part of the emotionally devastated son. At the other end are Julia, taking care of the mother to the end, and her older sister, who try to release the tension with nervous laughter. The deceased's husband, apparently the most grave, at some point irrationally demands to open the coffin to make sure that his beloved wife is really there. Afterwards he drinks himself to unconsciousness, unable to deal with his wife's death in any other way.

In Body/Ciało, the therapist, who is also a spiritualist, organizes sessions where she tries to contact the dead. In one of the scenes, a woman talks about her despair after her son's death, expressing at the same time her immense gratefulness for the possibility of 
contacting her son: I am at peace now. I have already received ten letters via our spiritualist Anna. I feel indescribable relief, gratefulness ... At first I did not believe it was really happening ... that I was so lucky to talk with my son, feel his presence again ... This scene is a perfect illustration of sociologists' theories, which state that religion is currently being deinstitutionalized in Polish society, where "subjective and individualized interpretations of faith are gaining importance and which leads to not only religious doubts but also to an overt negation of church teaching" (Mariański, 2004, p. 114). The protagonists of Body/Ciato, despite their beliefs in afterlife, do not seek consolation in the church or consultation with priests but in alternative practices contradictory to Catholicism.

The topic of Polish modern religiousness was shown in an interesting manner in Szumowska's second full length feature film-Stranger (2004). In this film, Szumowska tells the story of a change of character she undergoes during her pregnancy. To portray this change, the director uses both elements of Catholic rhetoric and New Age movement concepts. Ewa (Malgorzata Bela), a 22-year-old gas station employee, lives from day to day without any particular goal that would may make her life meaningful. Ewa, dressed in a loose blue suit in which she goes to work and an unattractive grey cap, reminds more of a stout boy than a young attractive woman. The sadness and resignation clearly showing on her face correspond with the colouring of the first part of the film dominated by shades of grey and black. The character, due to her unisex outfit, seems to be also devoid of the body which later on due to pregnancy is to be the source of joy and thorough change. Autumn greyness, trees devoid of leaves, and other elements of the presented world, such as Ewa's clothes and the places where she stays, become the external sign of sadness and melancholy experienced by the girl, who cannot find any meaning nor her place in the world. Situation changes dramatically because of Ewa's unplanned pregnancy, which makes her look more attractive and changes the way she dresses. Whereas in the initial scenes the protagonist appears as a withdrawn secretive tomboy, in the scene that follow she is presented as a beautiful woman who instead of wearing grey outfits starts to wear dresses underlining her womanly shapes.

According to New Age theories alongside with a change of character, the presented reality also changes - the sun comes out from the clouds and the autumn landscape changes into a spring revival of nature. It may be referred to as the so-called "cosmic network where each element is connected with another but none of them has privileged status" (Ban, 2008, p. 77). This symbiosis of human being with nature is particularly visible in the scene where the character stands in a meadow on the water bank and in the background leaves are blowing in the wind. The girl slowly undresses and her pregnant belly appears. What is important is the fact that Ewa, shown in this scene in the American cinematic frame, does not stand in the middle but slightly on the side; therefore viewers may get the impression that it is not the character that is the most important here, as it is in the classical mainstream cinema, but she is just an element of a larger whole. Therefore, Szumowska seems to suggest that all the elements of the presented world are equally important and none of them, even the main character, cannot be treated as superordinate.

One of the distinctive features of the New Age movement is the ennoblement of bodiness which here becomes the of sanctity nature. This way of thinking is grounded in holism which rejects anthropological dualism and reductionism, confronting body with the spirit and human being with its creator. Instead, holism offers a thesis according to which all reality comes from a one and only final source, which is characterized by Tin Ban as 
follows: "this one source, which is claimed to be god, the mind or an absolute serves as a base for a holistic conceptualization of reality. Hence, also body and spirit, the material and spiritual dimension of human existence are connected through the fact of common origin" (Ban, 2008, pp. 76-77). Contrary to Christianity, where the body is seen as an obstacle in spiritual life since it belongs to the secular world and is prone to all kinds of passions and unlimited lusts, in the New Age paradigm the body is not a threat in achieving spiritual transcendence. The body is here perceived as capable of influencing the spirit, "not only in the harmful way but also positive one. If the body is used properly it can develop magical power which can stimulate transformation of the negative mental and emotional states" (Ban, 2008, p. 79).

In this context, Ewa's pregnancy is the reason for her spiritual and mental change. Classes at the prenatal school, where Ewa together with her friend and other couples preparing for childbirth practices breathing techniques, transform into a ballet which is accompanied by piano music coming from outside the cinematic frame. Women preparing for childbirth move as ballerinas and their husbands assist with pirouettes. The viewers realize that this dance is actually the character's vision, but for the purpose of this paper it is a significant scene. Ordinary breathing exercises can become the source of a spiritual and mystical experience because "through physical exercise such as dance, tantric sex, and breathing techniques, the body can consciously cause ecstatic, mystical, and other spiritual experiences which is highly valued by seekers of new spirituality" (Ban, 2008, p. 79). Szumowska decides to present these raptures of the character through ballet-an art form, creating in many people a transcendental experience.

However, in Stranger, the director does not entirely reject elements of catholic doctrine. In the film, bodiness, which is the source of sacrum according to New Age, is integrated with martyrological elements dominant in Polish Catholicism. In this context Ewa may be seen as the Mother of God, who in Polish folk literature evokes rather human female traits, not the ones associated with Virgin Mary, the Queen of Poland:

What is striking in folk imagination is the scope of "supernational" incarnations of the Mother of God, which is summarized in the list by Ewa Rosa, a folk culture researcher. The list includes images of Madonna as the Mother of God and Mother of People, Dolorous Mother, Mother Hostess, Carer, Comforter, Advocate, Merciful Lady, Miracle Doer, Healer, and finally Hope of the Dying or Patroness of a Good Death -in one word the one people can confide in "all our daily matters" knowing that "she lives a simple life as we do" (Morstin-Popławska, 2010, p. 115).

By referring to seemingly distant paradigms-New Age and Catholicism-Matgorzata Szumowska modernises the cinematic image of a native woman about to become a mother. The spirituality of the protagonist, which is a collage of Polish religiousness with new elements derived from foreign cultures, may appeal to young Polish women who are seeking transcendence in their lives but cannot find it within the Orthodox Catholic Doctrine. The director concludes that they may find it by exploring nature and femininity questions.

By stressing changes in Polish religiousness, Szumowska seems to simultaneously indicate that the traditional institution of Polish Catholic Church is oppressed, not only for believers, but also for priests. In In the Name of... Szumowska tells the story of a homosexual priest who is time and time again forced to change his place of living. At first, he is working in a small Mazurian country and, for evident reasons, has to hide his true sexual orientation from others. 
It would seem that his attraction towards people of the same sex should automatically exclude him from the church community. Yet it turns out that the man feels true vocation and is a great priest, as is confirmed by the centre he runs sheltering difficult youth and the respect he gains among his pupils: "the way Andrzej Chyra, who plays the part, speaks in church to his parishioners shows a man who knows more than ordinary people. He gives his sermons which at the same time are not sermons. As a result people want to listen to him"-Piotr Śmiałowski states in his review (Śmiałowski, 2013, p. 64). The priest, trying to reconcile contradictory expectations (being in agreement with church learning) with a desire to have someone close (falling in love with one of the boys who is under his care), undergoes psychological breakdown which he finally recovers from when Dynia (Mateusz Kościukiewicz) who is in love with him, decides to knock on the priest's door...

In this film Szumowska decides to raise the difficult issue presented many times by Polish media in recent years - the homosexuality of priests. This difficult problem has been ignored and swept under the carpet by many ecclesiastical dignitaries. It is perfectly illustrated by the filmic bishop. After one of the parishioners reveals his suspicions concerning priest Adam, the bishop gives him a very hypocritical answer: The Church has to peer into any worrying issues. But in this case, I do not see anything strange, please, believe me. As a consequence, instead of solving the problem, the bishop decides to send the priest to a faraway parish, choosing in this way the simplest solution.

It does not mean that the director condemns the main protagonist, who is presented as a fully committed priest, but rather Szumowska reveals the mechanism which leads to the falsifying of the institution of Catholic Church and its blocking of the voices of believers. A great illustration of this phenomenon is another scene in which Adam would like to confess, but when he goes to the church he finds out that he can't because it is being vacuumed.

\section{CONCLUSION}

In her feature films, Małgorzata Szumowska defines Polish identity, according to Antonina Kłoskowska's theory, as a phenomenon which always exists in a specific social and cultural context. From this perspective, Polishness is constantly negotiated and renegotiated by film protagonists. Szumowska likes to deconstruct (in Jacques Derrida's terms) national myths, for instance Poles' attachment to Catholicism, and reveals the true image of Poles existing nowadays.

In the director's view, contemporary Polishness is strongly connected with traumas caused by tragic twentieth-century historical events-World War II, and after that communism present until 1989. Although, in none of her films does she directly speak about past traumas and action of her films take place in modern times; in almost all her films subtle references to national history are conveyed. The director is interested in contemporary Polish identity but presents its non-standard aspect, regarding it as a construct under permanent change. An illustration of this transformation is the peculiar religious syncretism, where Catholicism incorporates new elements, often contrary to the Catholic doctrine, like Spiritualism or New Age. Nevertheless, Małgorzata Szumowska recognizes differences still visible among young Poles in comparison to the people of Western Euro- 
pean nations which are also the consequence of Slavic roots of Poland. These differences are expressed in the term 'national character'.

Szumowska examines Polishness from a slightly ironic distance (which does not mean a lack of emotional involvement) and enters the discussion with national sanctities such as the Church or family. Her experience, working abroad and dealing with the realities of life in Western Europe, enables her to keep a distant perspective on her native country and results in an accurate diagnosis of contemporary Polish identity presented in films.

Matgorzata Szumowska and her protagonists could be regarded in this context as domestic foreigners whose language and cultural value systems, according to Rosi Braidotti's theory, are different from systems dominant in society, and as such her protagonists exhibit nomadic identity (Braidotti, 1994, p. 255). Szumowska's nomadism can be seen in the context of her relations with Poland which she laughs at and mocks and at the same time emphaticizes with, showing her deep devotion to homeland. Her characters very often feel alienated from the mainstream society because they are emigrants, like Alicja in Sponsoring or are of minority sexual orientation and alcoholics like priest Adam in In the Name of ... Different values and language, as described by Braidotti, can also be understood metaphorically, as painful experiences which make characters start functioning differently than the rest of society as is shown in 33 Scenes from Life or in Body/Ciało.

The cinema of Matgorzata Szumowska is critical towards inherited ways of defining Polish national culture as unchangeable and permanent. On the contrary, the director prefers regarding Polish identity as complex, full of divisions, differences, and contradictions. Accordingly, she endeavours to portray her Polish characters as more real and able to communicate something important about contemporary Poland, even to foreign viewers.

\section{REFERENCES}

Ban, T. (2008). Ciało w New Age. In K. Leszczyńska \& Z. Pasek (Eds.), Nowa duchowość w społeczeństwach monokulturowych i pluralistycznych. Kraków: Nomos, pp. 76-83.

Braidotti, R. (1994). Nomadic subjects: Embodiment and sexual difference in contemporary feminist theory. New York: Columbia University Press.

Giddens, A. (1991). Modernity and self-identity: Self and society in the late modern age. Stanford: Stanford University Press.

Greenblatt, S. (2006), Kultura (K. Kujawińska-Courtney, Trans.). In Poetyka kulturowa. Pisma wybrane (A. Rajca-Salata, Trans.). IKraków: Universitas, pp. 145-156.

Hannerz, U. (1996). Transnational connections: Culture, people, places. London: Routledge.

Hołda, R., (2012). Charakter narodowy. O przydatności pojęcia. In D. Czakon \& M. Boruta (Eds.) Kim jestem, kim jesteśmy? Antropologiczne i socjologiczne konteksty wspótczesnej tożsamości. Kraków: Wydawnictwo Naukowe Uniwersytetu Pedagogicznego, pp. 121-131.

Kaplan, A.E. (1999). Performing traumatic dialogue: On the border of fiction and autobiography. Women \& Performance: a journal of feminist theory, 10:1-2, pp. 33-58.

Kłoskowska, A. (2005). Kultury narodowe u korzeni. Warszawa: Wydawnictwo Naukowe PWN.

Lewandowski, E. (2008). Charakter narodowy Polaków i innych. Warszawa: Muza. 
Mandes, S. (2012). Życie religijne. In A. Giza \& M. Sikorska (Eds.), Wspótczesne spoteczeństwo polskie. Warszawa: PWN, pp. 229-269.

Mariański, J. (2004). Religijność społeczeństwa polskiego w perspektywie europejskiej: Próba syntezy socjologicznej. Kraków: Nomos.

Morstin-Popławska, A. (2010). Jak daleko stąd do raju?: Religia jako pamięć w polskim filmie fabularnym. Kraków: Universitas.

Piepiórka, M. (2013). Wszystko, co ludzkie. Kino, nr 9, pp. 20-23.

Pietrasik, Z., \& Szumowska, M. (2009). Jestem niepatriotką: Rozmowa z Małgorzatą Szumowską, laureatką Paszportu Polityki w kategorii film. Polityka, nr 5 (31.01.2009), pp. 59-61.

Rigamonti, M., \& Szumowska, M. (2012). Wystawiam język światu. Newsweek Polska, 2012, nr 6, (6.02.2012), pp. 46-49.

Sadowska, M. (2013). Pan jest blisko. Newsweek Polska, nr 7 (11.02.2013), pp. 80-83.

Sadowska, M. (2015). Czy salceson ma duszę? Newsweek Polska, nr 7 (9.02.2015), pp. 92-95.

Smith A.D. (2007). Nacjonalizm, E. Chomicka (Trans.), Warszawa: Wydawnictwo Sic!

Śmiałowski, P. (2013). W imię... Kino, nr 9, pp. 64-65.

Sztompka, P. (2000). Trauma wielkiej zmiany. Społeczne koszty transformacji, Warszawa: Instytut Studiów Politycznych Polskiej Akademii Nauk.

Wiśniewska, A. (2012). Szumowska: Kino to szkoła przetrwania. Warszawa: Wydawnictwo Krytyki Politycznej.

Zarębski, J. K. (2008). 33 sceny z życia. Kino, nr 11, pp. 75-76. 